Article

\title{
Expression of Genes Related to Carrageenan Synthesis during Carposporogenesis of the Red Seaweed Grateloupia imbricata
}

\author{
Pilar Garcia-Jimenez *(D), Sara R. Mantesa and Rafael R. Robaina \\ Departamento de Biología, Facultad de Ciencias del Mar, Instituto de Estudios Ambientales y Recursos \\ Naturales, Universidad de Las Palmas de Gran Canaria, E-35017 Las Palmas de Gran Canaria, Spain; \\ saramantesa@gmail.com (S.R.M.); rafael.robaina@ulpgc.es (R.R.R.) \\ * Correspondence: pilar.garcia@ulpgc.es
}

Received: 22 July 2020; Accepted: 18 August 2020; Published: 19 August 2020

\begin{abstract}
Carrageenan, the foremost constituent of extracellular matrix of some rhodophyta, is a galactan backbone with a different number of sulphate groups attached. Variations of degree of sulphation are associated with different types of carrageenans, which vary according to seaweed life cycles, and have consequences for the exploitation of this raw material. In this work, we used three well-recognised stages of development thalli and two stages of cystocarp maturation to analyse genes that encode addition and elimination of sulphate groups to cell-wall galactan of the red seaweed Grateloupia imbricata. Expressions of carbohydrate sulfotransferase and galactose-6 sulfurylase and genes encoding stress proteins such as cytochrome P450 and WD40, were examined. Results showed that transcript expression of carbohydrate sulfotransferase occurs at all stage of thalli development. Meanwhile galactose- 6 sulfurylase expressions displayed different roles, which could be related to a temporal regulation of cystocarp maturation. Cytochrome P450 and WD40 are related to the disclosure and maturation of cystocarps of G. imbricata. Our conclusion is that differential expression of genes encoding proteins involved in the sulphation and desulphation of galactan backbone is associated with alterations in thalli development and cystocarp maturation in the red seaweed Grateloupia imbricata. Exploitation of industry-valued carrageenan will depend on insight into gene mechanisms of red seaweeds.
\end{abstract}

Keywords: carbohydrate sulfotransferase; carrageenan; cytochrome P450; galactose-6 sulfurylase; red alga; reproduction stages; WD 40

\section{Introduction}

Red seaweed cell-walls are mainly made of complex sulphated galactans primarily agar and carrageenans, which comprise a large family of hydrocolloids, depending on the varying degree of sulphation [1-3]. Specifically, carrageenans can be classified according to their gel-forming ability [4]. The differences among the various forms of carrageenan ( $\mathrm{k}-\mathrm{l} \mathrm{l}$ - and $\lambda$-carrageenans) are related to the amount of sulphate groups, affecting solubility in water and the strength of carrageenans [5]. Moreover, cell walls have to change their carrageenan composition to adapt to the different development stages of the seaweed [6]. Thus, carragenophytic-alga gametophytes are known to be composed of $k$ - and ı carrageenan, whereas tetrasporophytes have $\lambda$-carrageenan [4].

Seaweed responses to the presence of reproductive structures is to push thallus cells to the sides, generate anatomical changes to locate reproductive structures and trigger fluctuations in the composition of the cell wall [4,7]. As the integrity of the cell wall is essential for maintaining growth and development of alga thalli and for the survival of reproductive structures, alterations in carrageenan 
composition can be assumed, as galactose units work together to build, incorporate and remove sulphated groups to and from the growing strands of galactans. Furthermore, these changes in the amount of sulphate groups influence the ability of seaweed to model responses, such as the softening and flexibility of thalli and facilitating the growth in size of reproductive structures. Seaweed can also display responses for recovering of thallus status after sporogenesis.

Additionally, sporogenesis is inherently linked to stressors such as volatile growth regulators, tide periods, hours of irradiation and temperature [8-10]. These environmental stressors also have an impact on generating reactive oxygen species (ROS in the form of $\mathrm{O}_{2}, \mathrm{H}_{2} \mathrm{O}_{2}$ or $\mathrm{OH}^{-}$) $[9,10]$. Moreover, ROSs also play an important role in softening thalli and therefore also facilitate the development of cystocarps in red seaweed [8]. Reactive oxygen species act as signalling molecules under stress and induce cell responses [11,12]. Moreover proteins, such as WD40 and cytochrome P450, can be synthesised to reduce such oxidative damage $[9,10,13]$. Carrageenans, as components of the cell wall in seaweeds, have been reported to also show antioxidant activity by scavenging hydrogen peroxide [14,15].

Consistent with the chemical complexity of the cell wall and multiple environment stressors, the transcriptional machinery underlying synthesis and modification of cell-wall polysaccharides is intricate. Particularly in the case of carrageenans, the biosynthesis pathway has not been fully described, although three main classes of enzymes have been proposed namely galactosyltransferases, sulfotransferases and galactose 6 sulfurylases [16]. Significantly, carbohydrate sulfotransferase, which add a sulphate group from a donor molecule (often 3 'phosphoadenosine-5'phosphosulfate, PAPS), have been described in carrageenophytes. Galactose- 6 sulfurylase, which catalyses the formation of the 3,6-anhydrogalactose residues by removing C6 sulphate group in sulphated galactans [17], has also been reported specifically in red macroalgae (Figure 1).

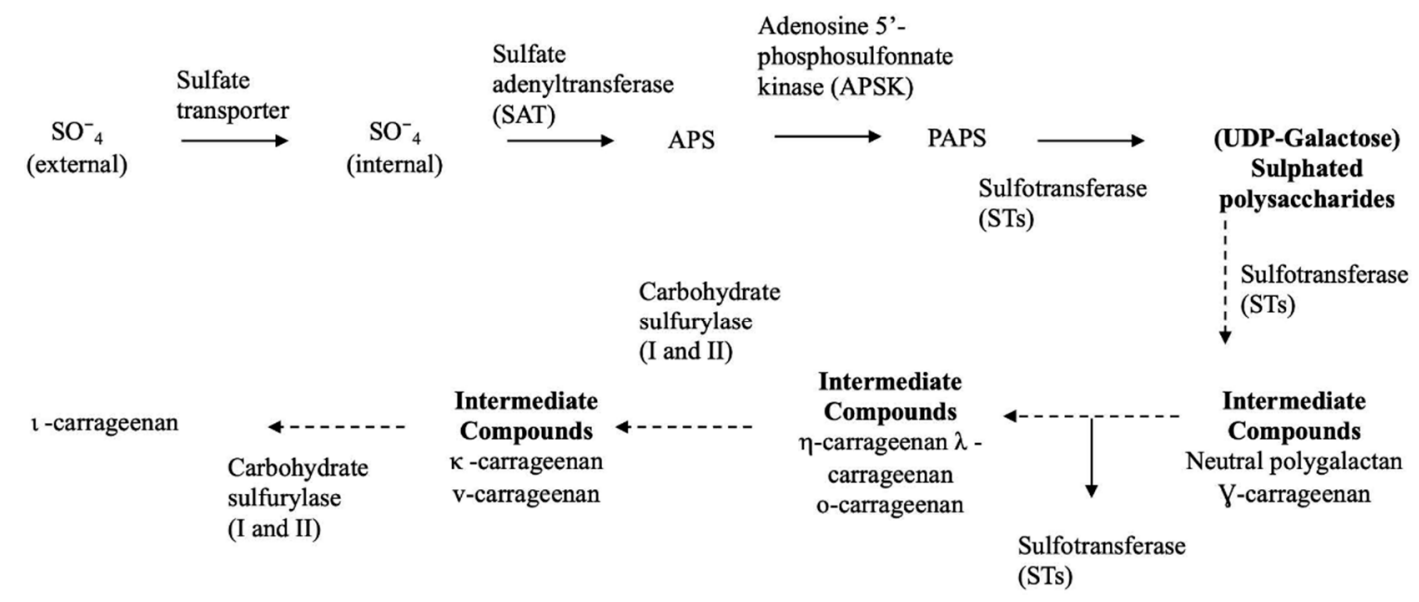

Figure 1. Schematic biosynthetic pathway for sulphate assimilation and synthesis of carrageenan. PAPS, 3'phosphoadenosine-5' phosphosulfate.

Grateloupia imbricata is a carragenophytic red seaweed, with triphasic life cycle (Figure 2). This macroalga represents a candidate model organism for basic studies of physiology, owing to its ability to produce raw material such as carrageenan. 


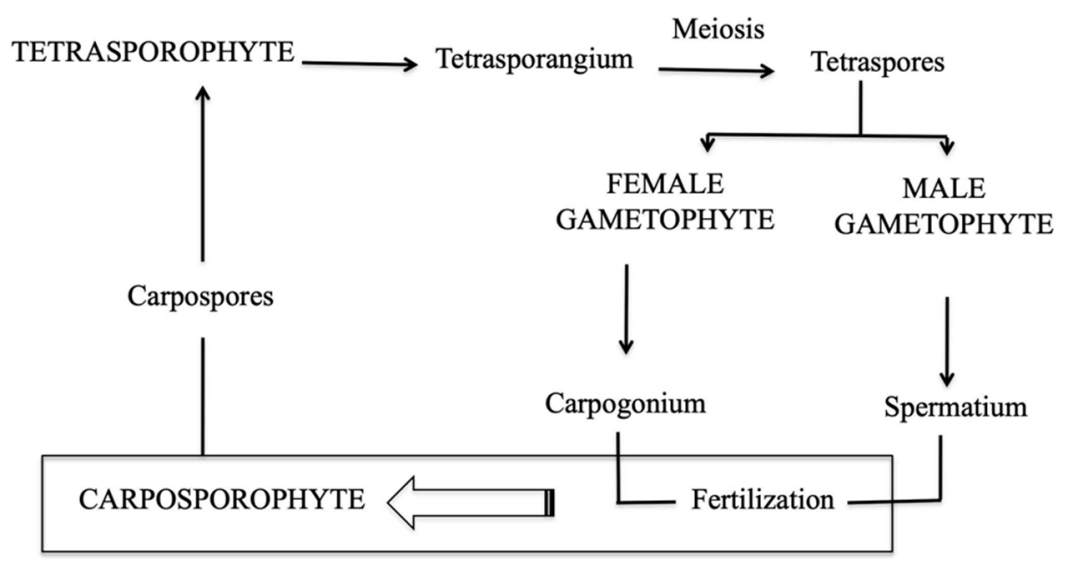

Figure 2. Diagram of a tri-genetic life cycle in the red alga Grateloupia imbricata comprising gametophytes (haploids), the carposporophyte, that develops on the female gametophyte after fertilisation, and the sporophyte (diploid). Taken from Garcia-Jimenez and Robaina (2019) DOI: http://dx.doi.org/10.5772/ intechopen.83353.

Transcriptome information of G. imbricata revealed the presence of transcripts required for biosynthesis of sulphated polysaccharides, so the study of these transcripts can contribute to the understanding of carrageenan synthesis [18]. This paper focuses on the characterisation of expression of genes such as carbohydrate sulfotransferase and galactose 6 sulfurylase that are specifically related to addition and removal of sulphate groups to galactan. We hypothesised that the expression of genes encoding enzymes of carrageenan synthesis in G. imbricata can be a starting point for further studies on sulphation of carrageenan. Moreover, these genes can be correlated to reproductive stage (carposporogenesis) of G. imbricata. Our aim is to show that the expression of two genes involved in the sulphation (carbohydrate sulfotransferase) and desulphation (galactose-6 sulfurylase) of the galactan backbone is related to the stage of development of thalli and to reproductive structures (cystocarps) through flexibility and softening of thalli. Likewise, we determine to what extent genes encoding stress proteins (Cytochrome P450 and WD 40) can also be involved during cystocarp maturation, as the presence of cystocarps would also comprise the cell wall softening.

\section{Results}

To determine the sulphation and desulphation of galactan, transcript expressions of carbohydrate sulfotransferase in charge of addition sulphate groups and galactose- 6 sulfurylase for removing sulphate groups were determined according to development stage of thalli and to the presence of reproductive structures (cystocarps; Figure 3).

\subsection{Gene Expression for Stages of Thalli Development}

Expression levels of each of two gene sequences encoding sulfotransferase and sulfurylase for infertile, fertilised and fertile thalli are shown (Figure 4). Expressions for sulfotransferase, ST1 and ST2, exhibit similar behaviour (Figure 4A). In addition, no significative differences in levels of expression are reported between different stages of development of the thalli (Figure 4A).

Different transcript expressions are shown for sulfurylase depending on the development stage of the thalli. Thus, when transcript expression for sulfurylase 1 (SY1) was compared to that of infertile thalli, $S Y 1$ was overexpressed for fertilised thalli and down expressed for fertile thalli (Figure 4B). Meanwhile the transcript expression for $S Y 2$ was significantly down-expressed for fertilised and fertile thalli, compared to infertile thalli (Figure 4B). Significant differential expression is also reported when sulfurylase SY1 and SY2 from fertilised thalli are compared. 


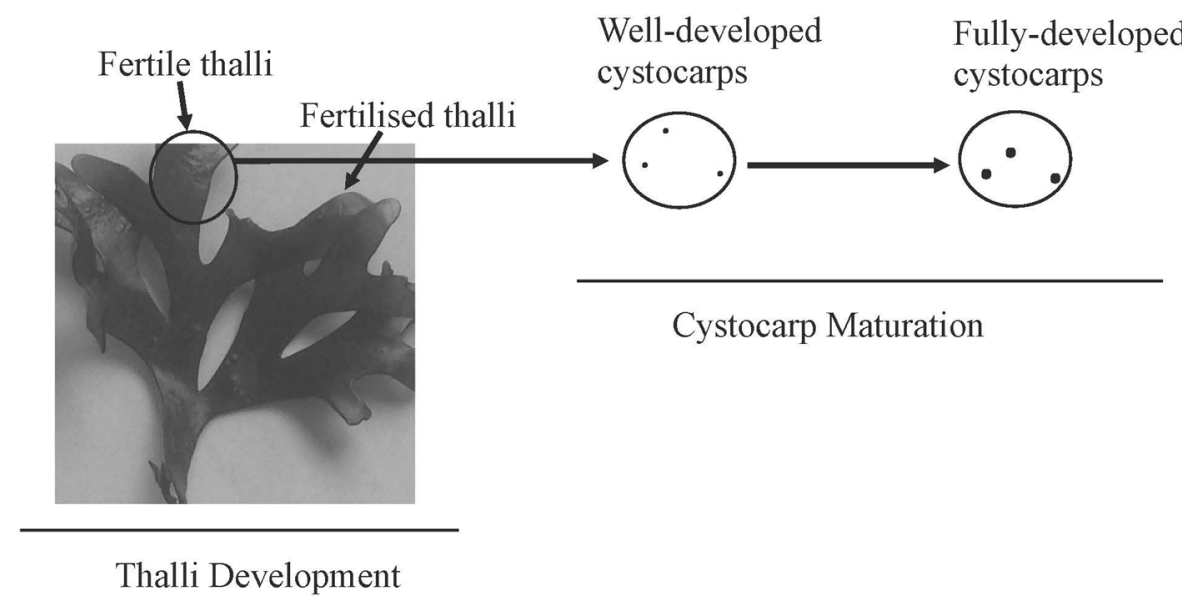

Figure 3. Schematic showing different development stages of thalli (fertilised and fertile thalli) and cystocarps maturation (well-developed and fully-developed cystocarps) of Grateloupia imbricata. Infertile thalli are thalli without cystocarps in all axes of the same individual.

\subsection{Gene Expression for the Maturation of Reproductive Structures (Cystocarps)}

Expression levels of sulfotransferase (ST1 and ST2) in the presence of fully-developed cystocarps show significant over-expression compared to the absence of cystocarps and well-developed cystocarps (Figure 5A,B).

Regarding sulfurylase, expression levels of $S Y 1$ and $S Y 2$ show different behaviours. On the one hand, sulfurylase $S Y 1$ is over-expressed in well-developed cystocarps in comparison with fully-developed cystocarps (Figure 6A).

On the other hand, sulfurylase SY2 is expressed significantly in the presence of fully-developed cystocarps. Thus, this expression was related to the maturity of the cystocarps (Figure 6B).

\subsection{Gene Expression Encoding Stress Proteins during Cystocarp Maturation}

Levels of the expression of Cytochrome P450 and WD 40 follow a similar pattern (Figure 7). No significant differences were found in the Cytochrome P450 and WD 40 expression levels in thalli with well-developed cystocarps when compared to those without cystocarps (dotted line, Figure 7). The gene transcript expression is only significant for WD40 in fully-developed cystocarps in comparison with well-developed cystocarps (Figure 7). 


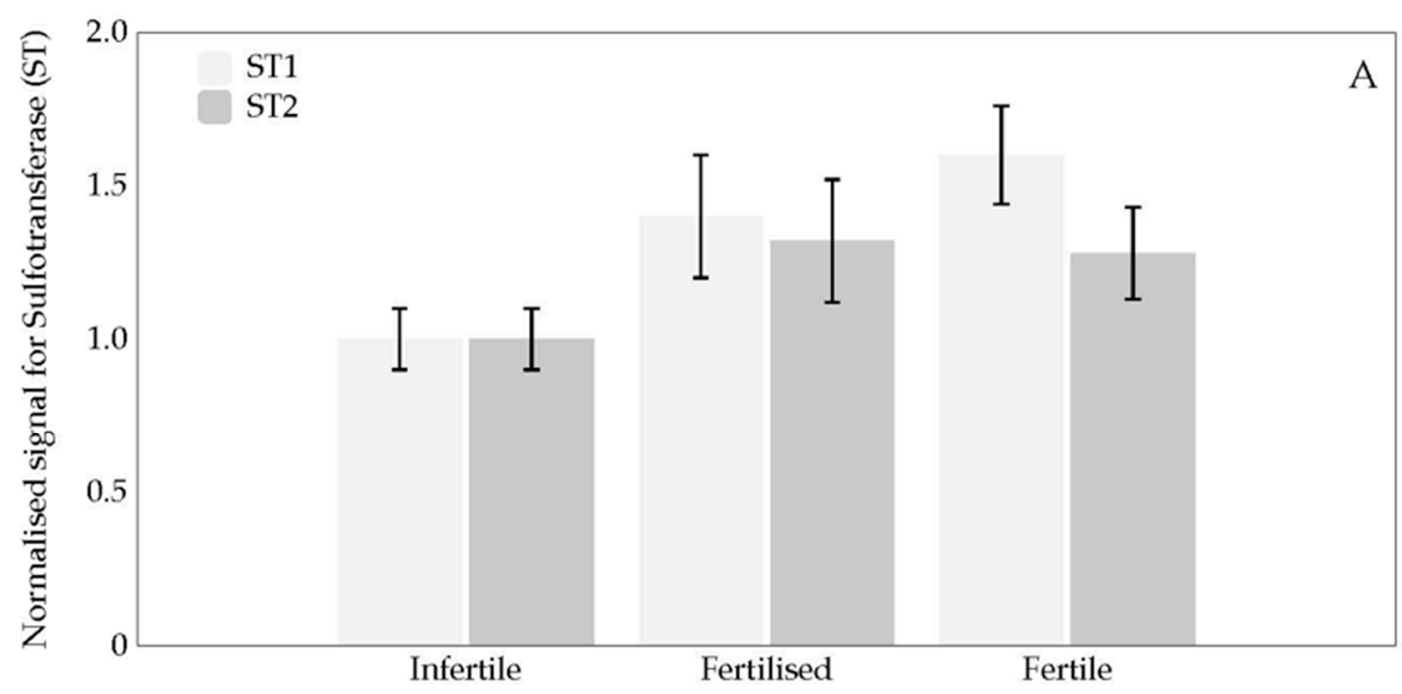

Maturity stages of thalli

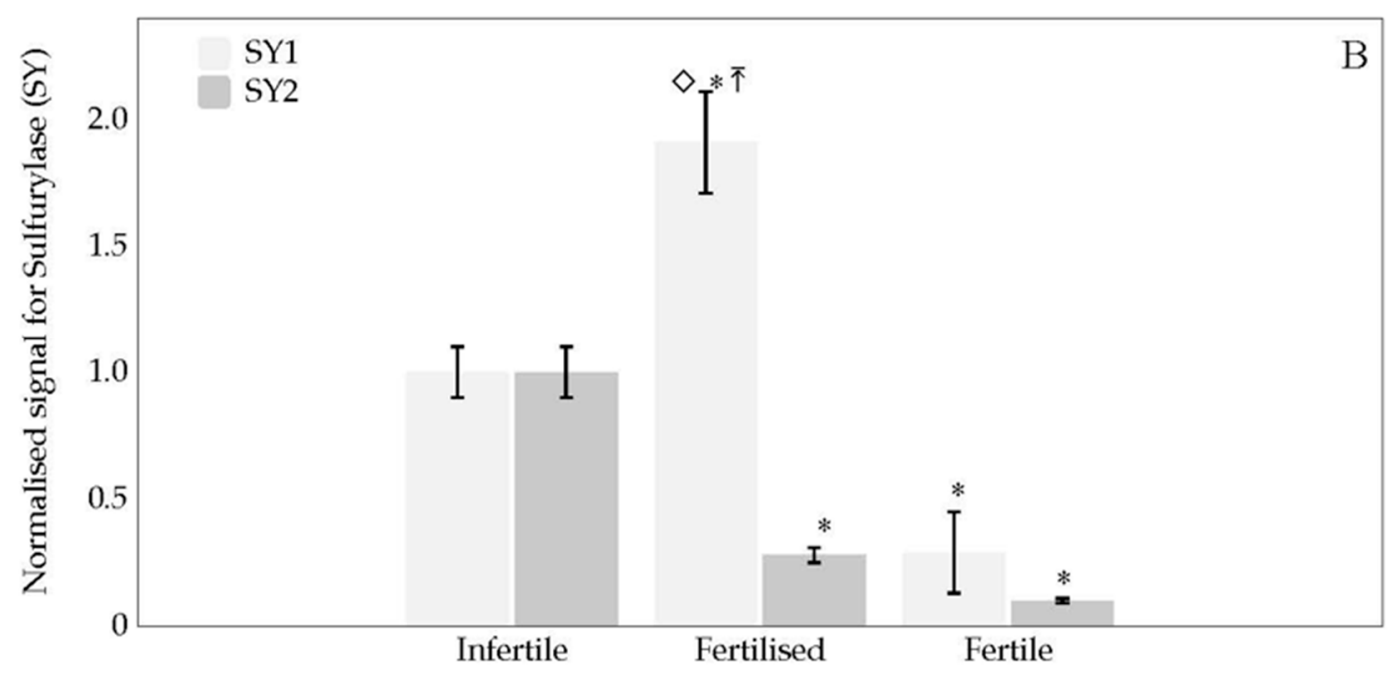

Maturity stages of thalli

Figure 4. Normalised expression signal during three thalli development stages (infertile, fertilised and fertile thalli) of Grateloupia imbricata for (A) two carbohydrate sulfotransferase (Sulfotransferase, ST1 and ST2); (B) two galactose-6 sulfurylase (Sulfurylase SY1 and SY2). Data in bars are the mean \pm SD, $n=4$. Different symbols mean significant differences $(p<0.01)$ between infertile thalli and fertilised and fertile thalli $(*)$, between two gene sequences 1 and $2(\kappa)$, and between different stages of development $(\diamond)$. 

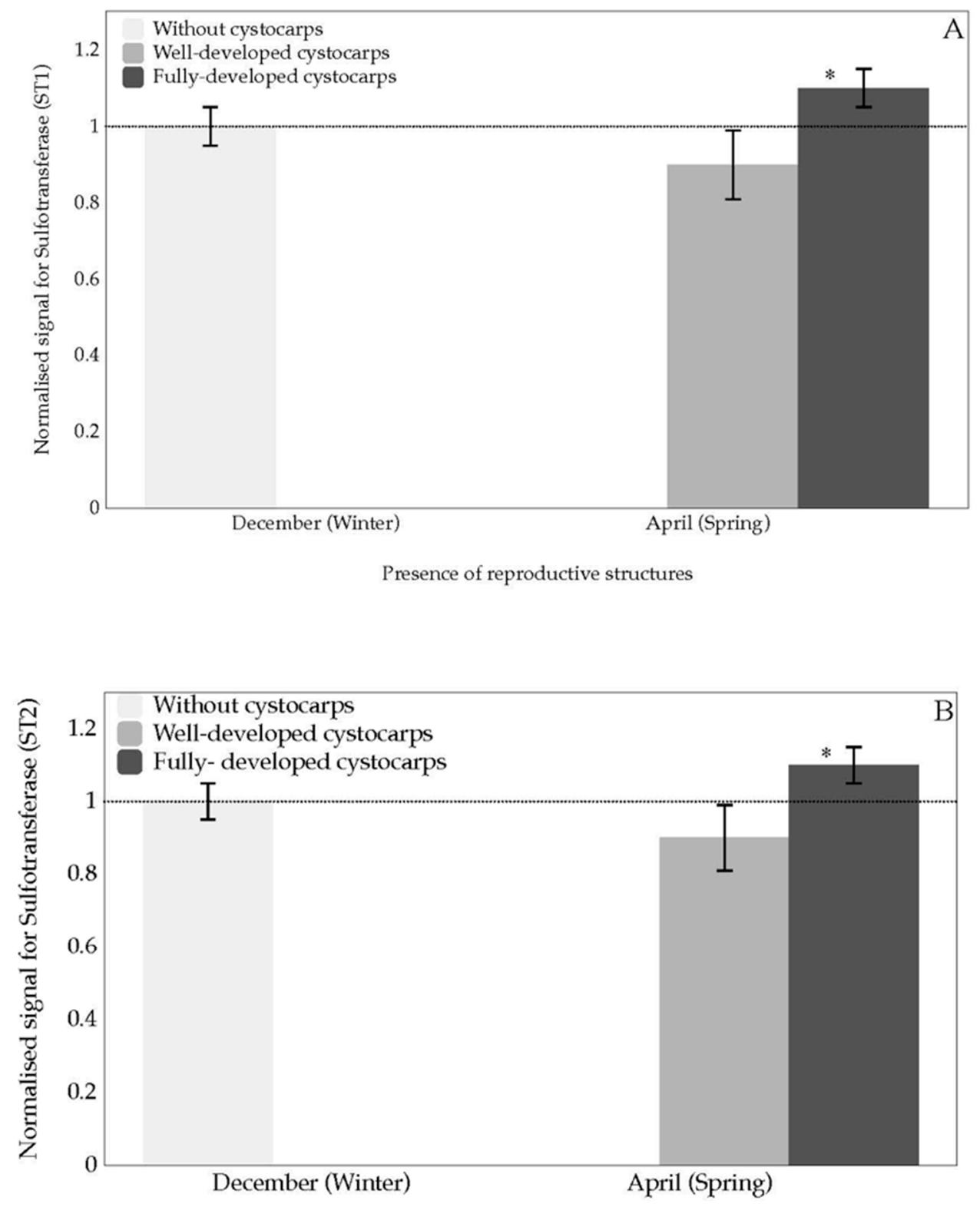

Presence of reproductive structures

Figure 5. Normalised expression for carbohydrate sulfotransferase during two stages of cystocarps maturation (well-developed and fully-developed cystocarps) of Grateloupia imbricata for (A) Sulfotransferase, ST1; (B) Sulfotransferase, ST2. Data in bars are the mean $\pm \mathrm{SD}, n=4$. ${ }^{*}$ significant differences $(p<0.01)$ between samples without cystocarps and at different maturation stages. Dotted line corresponds to transcript expression from pooled thalli containing cystocarps at different stages of development and thalli without cystocarps $(n=8)$. 


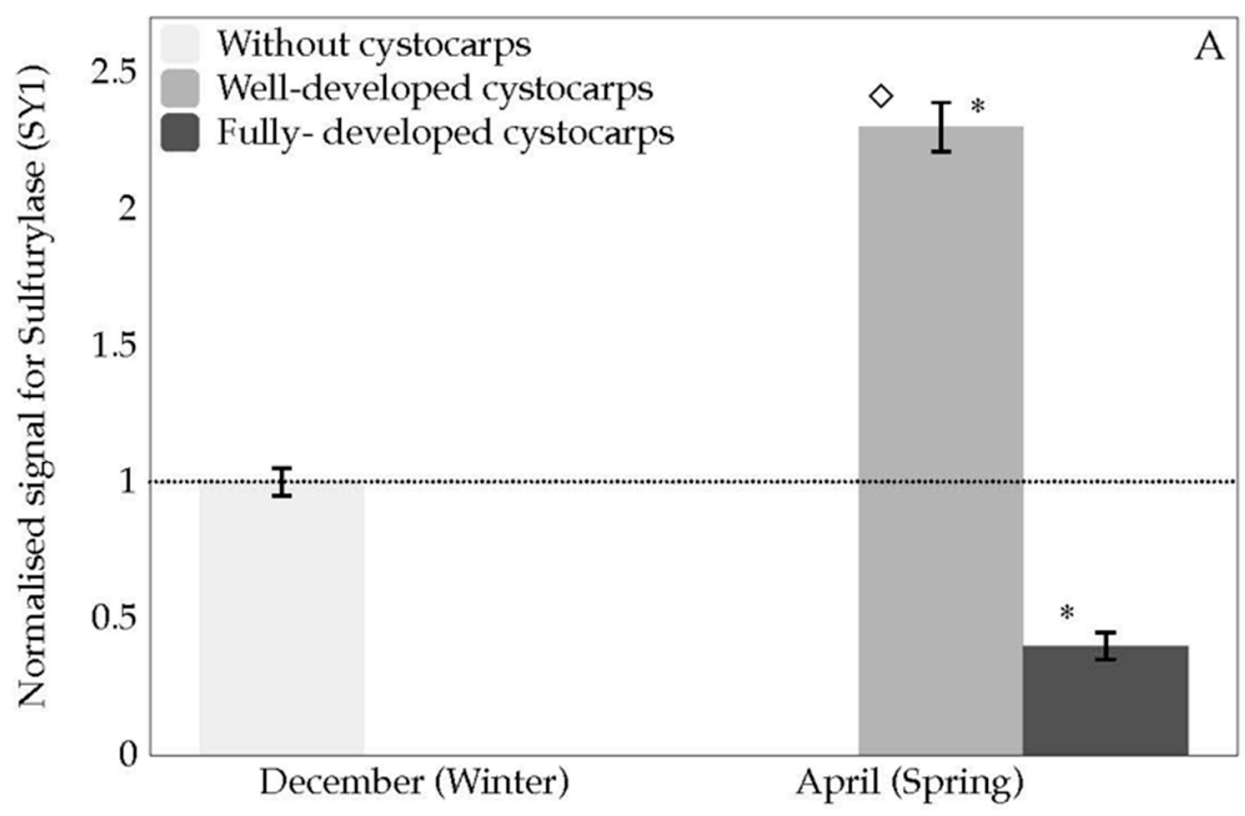

Presence of reproductive structures

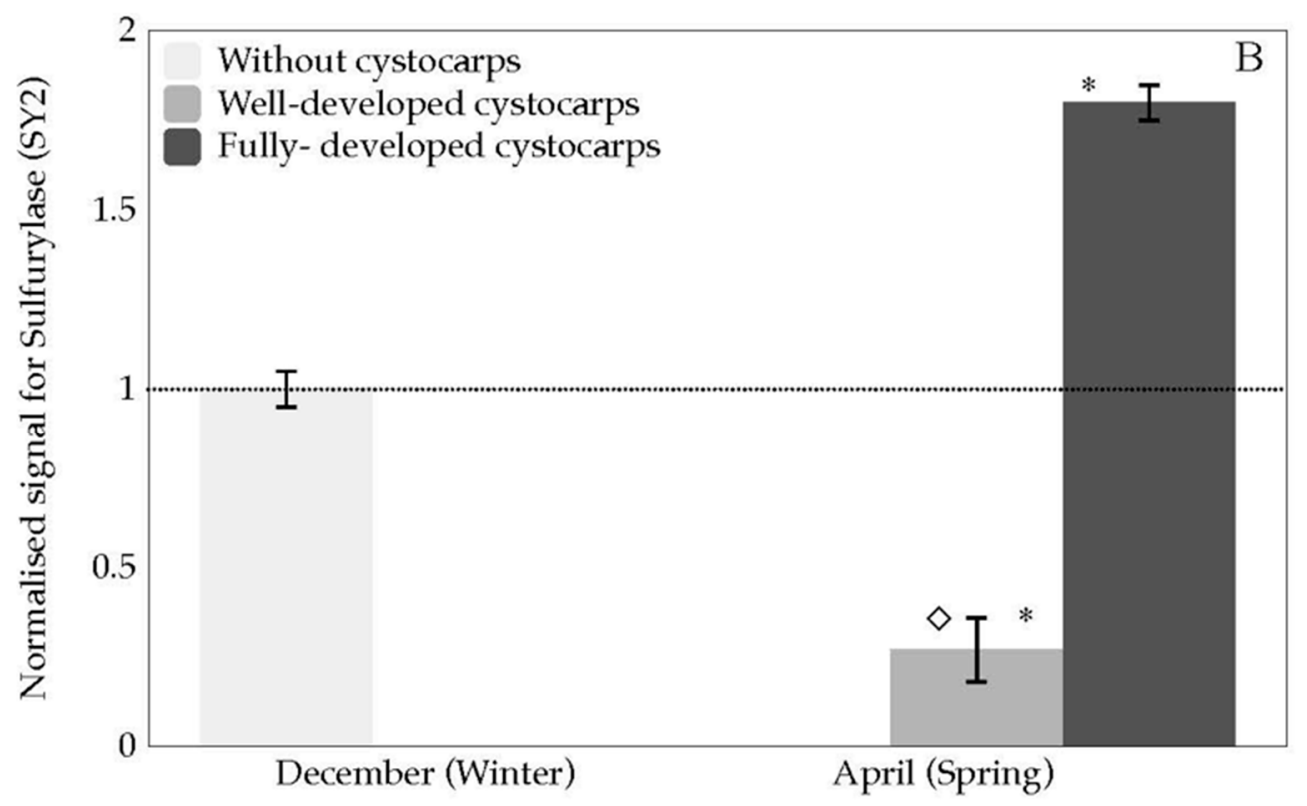

Presence of reproductive structures

Figure 6. Normalised expression for galactose-6 sulfurylase during two stages of cystocarps maturation (well-developed and fully-developed cystocarps) of Grateloupia imbricata for (A) Sulfurylase SY1; (B) Sulfurylase SY2. Data in bars are the mean $\pm \mathrm{SD}, n=4$. Different symbols mean significant differences $(p<0.01)$ between samples without cystocarps and at different maturation stages $\left({ }^{*}\right)$, and between different stages of cystocarps maturation for the same gene $(\diamond)$. Dotted line corresponds to transcript expression from pooled thalli containing cystocarps at different stages of development and thalli without cystocarps $(n=8)$. 


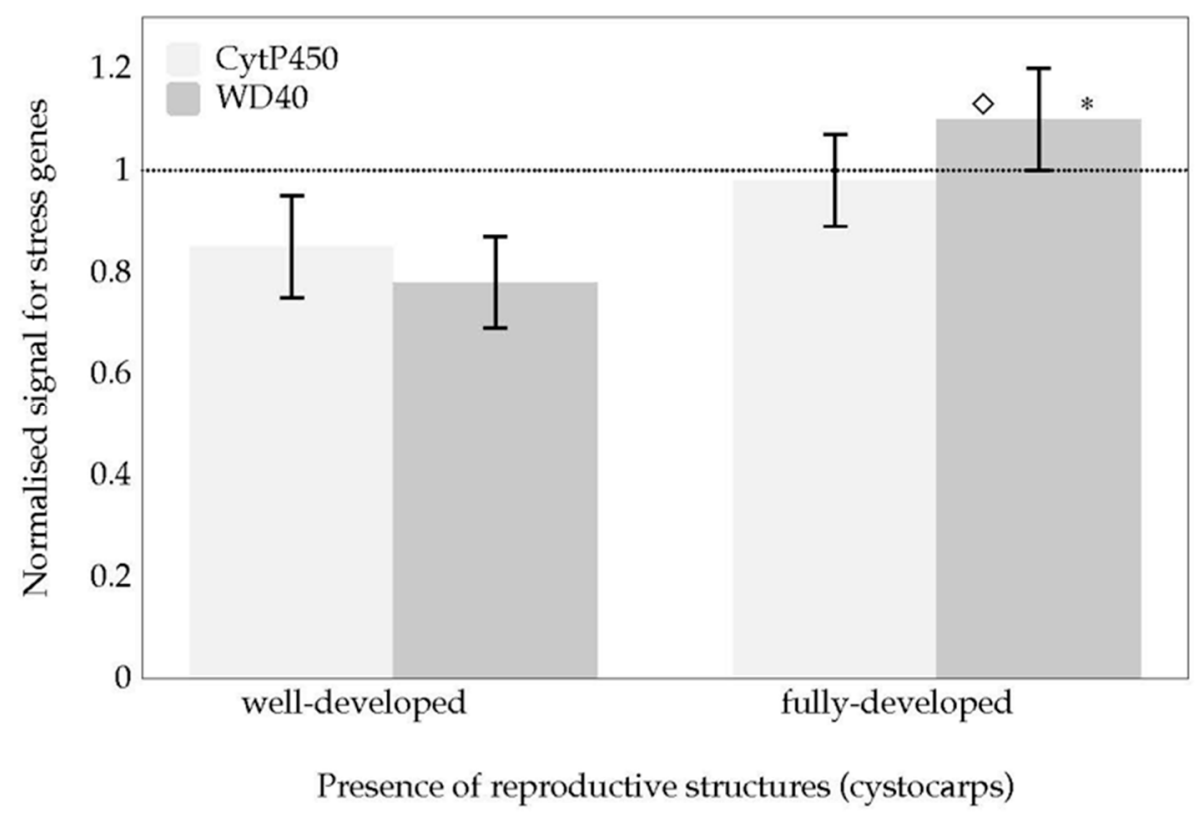

Figure 7. Normalised expression for Cytochrome P450 and WD40 during two stages of cystocarps maturation (well-developed and fully-developed cystocarps) of Grateloupia imbricata Data in bars are the mean $\pm \mathrm{SD}, n=4$. Different symbols mean significant differences $(p<0.01)$ between thalli with cystocarps and those without them $\left({ }^{*}\right)$, and between different stages of cystocarps maturation for the same gene $(\diamond)$. Dotted line corresponds to gene transcript expression of thalli without cystocarps $(n=8)$.

\section{Discussion}

Seaweed cell-wall is made of different components namely cellulose, xylan, mannan, among others [19], although important constituents are alginates and fucans for brown algae, ulvans and other sulphated glycans for green algae, and agar and carrageenan for red algae [20]. The latter complex group of components are also sulphated polysaccharides which are recognised by their pharmacological and industrial uses [21]. In Rhodophyta, agar and carrageenan account for $40-50 \%$ of the dry weight, but can be as much as $70-80 \%$ [20]. Focusing on carrageenans, the backbone structure comprises linear chains of repeating D-galactose sugars and 3,6-anhydro-galactose units, with a different number and location of the sulphate groups attached. Sulphation degree and molecular conformation allow classifying carrageenans in three main types with commercial importance, namely $\mathrm{K}$-, l- and $\lambda$-carrageenan, all containing $15-40 \%$ ester sulphate; although seaweeds can also contain hybrids carrageenans [22]. Sulphation takes place in the cell wall by the action of carbohydrate sulfotransferase whilst desulphation by galactose-6 sulfurylase also occurs in the cell wall, although its role is not fully clarified. Galactose- 6 sulfurylase catalyses the conversion of $\mu$-carrageenan into $\kappa$-carrageenan, but $\lambda$-carrageenan seems to not be susceptible to its action $[16,23,24]$. The number of sulphate groups is, in turn, one of the features that affects the properties of carrageenan types as carrageenans are gel-forming and viscosifying polysaccharides [25]. In addition, variations in carrageenan composition, i.e., sulphation degree, have been associated to life cycles stages of algae, alga species and environment conditions.

With the goal of revealing changes in sulphation degree of galactan of carrageenan during carposporogenesis in G. imbricata, expression levels of two genes involved in the biosynthesis of carrageenan has been reported. One of main achievements of this work lies on the fact that changes in transcript levels of these genes, i.e., carbohydrate sulfotransferase and galactose-6-sulfurylase, are associated at different stages of thalli development and the well-recognised stages of cystocarp maturation. Thus, expressions of sulfotransferase were reported in all stages of thalli development (Figure 4A). Results indicated that (1) the ST1 and ST2 could encode proteins responsible for similar mechanisms 
and metabolic pathways during thalli development, and (2) sulfotransferase could be involved in housekeeping activity as sulphated galactan is component of cell wall of red seaweeds. Hence, transcript expression suggests that the addition of sulphate groups occurs during all stages of thalli development.

It is also worth drawing attention to the behaviour of both sulfurylase sequences (Figure 4B). The expression behaviour of sulfurylase (SY1 and SY2) indicated that they may play several roles and that they are time-regulated. It was also evident that $S Y 1$ was induced to a larger extent when the thalli were fertilised (Figure 4B). Noticeably, overexpression was higher in sulfurylase SY1 than sulfurylase SY2 for fertilised thalli, suggesting a concrete development-specific expression role for the sulfurylase SY1 gene during thalli maturation. Apart from that, sulfurylase SY2 expressions may also depend on the stage of the thalli, as differential transcript expression was also reported, albeit with different expression levels that were significantly lower than those for sulfurylase SY1 (Figure 4B). The exhibition of these expression patterns for $S Y 1$ and $S Y 2$ in the red seaweed G. imbricata opens up an interesting pathway for determining whether the differential expressions of $S Y 1$ and $S Y 2$ could be a consequence of specific transcription factors of each gene copy. Interestingly, it could infer the presence of specific transcription factors, which would only function efficiently at specific stages of thalli maturation. Hence, the different stages of seaweed thalli development could contribute to the expression of different regulatory proteins. In higher plants, different proteins can participate as elements of regulatory mechanisms and co-ordinate cell activity [26]. Furthermore, if the transcription factors were activated and regulatory proteins were synthesised, this would reinforce the theory of a time-gene regulation of two sulfurylase as thalli development proceeds. All in all, genes that encode proteins responsible for the desulphation of the galactan skeleton of the cell wall will allow G. imbricata thalli to soften and enable the development of reproductive structures (cystocarps) in thalli.

Cystocarp disclosure is elicited by complex multiple factors, encompassing the period from when cystocarps first become visible (well-developed cystocarps), through to the adequate development of cystocarps (fully-developed cystocarps). Thus, cystocarps could achieve optimal maturity when elicitation factors and the mechanisms that weaken and soften the cell wall act in co-ordination [8]. In line with this, the behaviour of the genes that encode the adding and elimination of the sulphate group during maturation of reproductive structures must be appraised, along with the genes that encode oxidative-stress-related proteins, which also potentially contribute to softening the thallus.

Little has been reported to date about genes that control sulphate addition. This is one of the few studies aimed at characterising sulfotransferase expression levels at different stages of maturity in red seaweed cystocarps. Although monitoring the expressions of two types of sulfotransferase (ST1 and ST2) showed similar behaviour and transcript expression levels, significant transcript expression was shown in fully-developed cystocarps of G. imbricata (Figure 5A,B). Our results seem to suggest that genes encoding proteins that add the sulphate group are working to reconstitute the cell wall after disclosure and maturity of cystocarps and even early release of spores, as this is an unsynchronised process. Thus, it would not be misconceived to think that once fertilisation has occurred in G. imbricata, the re-arrangement of carrageenan constituents proceeds to improve and recover the organisation of the cell wall.

Remarkably, what occurs with sulfurylase differs from the expected. Following the line of argument, the thalli would soften prior to the appearance of cystocarps. Hence, one would expect transcript overexpression of sulfurylase to be reported when cystocarps are first developing (well-developed cystocarps) and always prior to their complete maturity (fully-developed cystocarps). However, SY2 showed transcript expression is significantly higher in the presence of fully-developed cystocarps than in thalli with well-developed cystocarps (Figure 6B). Thus, different functionality of $S Y 1$ and SY2 can be assumed. To gain greater insight into what could be occurring, it is worth considering that fertilisation in G. imbricata takes place when a spermatium fertilises a carpogonium on the female gametophyte. The fertilised carpogonium develops into a structure called a cystocarp that will contain spores [27]. This cystocarp develops in the auxiliary ampulla after the auxiliary cell receives the diploid 
nuclei from the fertilised carpogonial cell [28]. Thus, carrying the argument of $S Y$ different functionality a step further, $S Y 1$ may be responsible for weakening the cell wall to embrace the development of auxiliary ampulla cells, and $S Y 2$ allows the cystocarps to grow in size and develop their spores within. These differentiated functions should show a co-ordination of the different kinds of sulfurylase over time and cell type during the cystocarp maturation. In short, this time-transcript expression could orchestrate specific adaptation and protective responses during cystocarps development. This would mean that sulfurylase genes are closely related to reproductive development and that maturity stages of cystocarps require genes expressed in different ways from early stages.

Beyond the sulphation and de-sulphation of galactan backbone as a consequence of thalli development and cystocarp maturation, the gene encoding WD40 has also been reported to potentially play a role in cystocarp maturing, as the gene transcripts were significantly overexpressed in fully-developed cystocarps, compared with expression in developing cystocarps (Figure 7). To some extent, these results are to be expected as earlier studies on gene expression during carposporogenesis of G. imbricata showed WD40 and cytochrome P450 transcript expressions are limited to different signals related to both cystocarp disclosure and development of the red seaweed G. imbricata $[9,10]$. Specifically, WD40 plays an active role in the processes of regulation and response to damage [29], so WD40 gene expression in G. imbricata could suggest cross talk between cystocarp maturation and a reduction of oxidative damage.

In summary, gene expressions involved in the sulphation and desulphation of galactan backbone are associated with alterations in thalli development and cystocarp maturation in the red seaweed G. imbricata. This opens an interesting framework to gain insight into gene mechanisms involved in carrageenan synthesis.

\section{Materials and Methods}

\subsection{Alga Material}

Thalli from G. imbricata were collected along the northeast coast of Gran Canaria in the Canary Islands. Within $2 \mathrm{~h}$ of collection, thalli were examined under a stereomicroscope to identify cystocarps. Axes with no visible cystocarps (henceforth, fertilised thalli) and axes with light-red dots that are indicative of cystocarps (henceforth, fertile thalli), both belonging to the same individual (i.e., anchored to the same basal structure), were identified and separated for further use.

Two categories of fertile thalli were also identified; thalli with well-developed cystocarps and those that have fully-developed cystocarps (intense red dot and referred to as mature; Figure 3). Infertile thalli without any cystocarps were used as controls.

\subsection{RNA Extraction}

Total RNA from G. imbricata samples was isolated, as previously described [30]. In short, total RNA was extracted separately from the apical regions (100 mg) of fertilised, fertile, and infertile G. mbricate thalli using $1 \mathrm{~mL}$ of Tri-Reagent (Sigma, St. Louis, MO, USA) pursuant to the manufacturer's instructions. The isolated RNA samples were suspended individually in $20 \mu \mathrm{L}$ of $1 \mathrm{M}$ Tris- $\mathrm{HCl}$, pH 8, 0.5 M EDTA and treated with DNase (1 $\mathrm{U} \mathrm{mg}^{-1}$; Promega, Madison, WI, USA) to destroy contaminating DNA. Total RNA was quantified in a TrayCell cuvette using a Beckman Coulter DU 530 spectrophotometer.

RNA ( 1 $\mu \mathrm{g}$ from each sample) was reverse transcribed to first strand cDNA using an iScript Select cDNA Synthesis Kit (Bio-Rad; Hercules, CA, USA). The reverse transcriptase reaction was performed at $25{ }^{\circ} \mathrm{C}$ for $5 \mathrm{~min}, 42{ }^{\circ} \mathrm{C}$ for $30 \mathrm{~min}$, and $85^{\circ} \mathrm{C}$ for $5 \mathrm{~min}$. The integrity of the cDNA was validated using a Nanodrop spectrophotometer (ThermoFisher Scientific, Waltham, MA, USA). The products were kept at $4{ }^{\circ} \mathrm{C}$ until used. 


\subsection{Quantitative Gene Expression}

Before assaying for gene expression, a temperature gradient protocol was implemented for each set of primers to establish the best experimental conditions. The efficiency of the amplification and primer-dimer formation was assessed using a melting curve.

Real-time PCR was performed using SYBR Green master mix (Bio-Rad) and a forward and reverse primer pair (Table 1). Primers were designed from cDNA sequences of the G. imbricata transcriptome (BioProject record PRJNA309128). cDNA (2.5 $\mu \mathrm{L})$ from apical parts of thalli in different maturity stages were used as a template. Real time PCR reactions were carried out with four replicates of each sample in a real-time PCR MiniOpticon thermal cycler (Bio-Rad) using the following steps: initial denaturation at $98^{\circ} \mathrm{C}$ for $1 \mathrm{~min}$, amplification during 30 cycles at the pertinent temperature for $1 \mathrm{~min}$ (Table 1$), 72{ }^{\circ} \mathrm{C}$ for $5 \mathrm{~min}$, followed by a final extension at $72{ }^{\circ} \mathrm{C}$ for $10 \mathrm{~min}$.

All gene expressions were normalised using methods to validate potential constitutive genes along with the GenNorm basic visual application following calculations described in [31]. Five housekeeping genes were selected and tested, as previously described [32]. Two of the five constituent genes were validated as housekeeping genes that encode a large subunit of ribosomal RNA and the elongation factor $1 \alpha$. We used amplicons ( $70 \mathrm{nt})$ selected from conserved regions of the large subunit of the ribosomal RNA of Grateloupia turuturu (DQ364073), Halymenia schizymenioid (DQ364067) and Cryptonemia undulata (AF419133) and from the elongation factor of Chondrus crispus (CO653259) and Haematococcus pluvialis (DV203478) to follow the expression of genes. Data were represented as relative to the expression in infertile thalli and were expressed as the mean \pm SD from four separate experiments.

Table 1. Sequences of the forward (F) and reverse (R) primers, and temperature of annealing (Tm) for each gene: Carbohydrate sulfotransferase (ST1 and ST2), Galactose-6 sulfurylase (SY1 and SY2), WD 40 and Cytochrome P450.

\begin{tabular}{|c|c|c|c|c|}
\hline $\begin{array}{l}\text { Contig from } \\
\text { Grateloupia imbricata } \\
\text { Transcriptome }\end{array}$ & Primer Name & & Sequence $\left(5^{\prime}-3^{\prime}\right)$ & $\operatorname{Tm}\left({ }^{\circ} \mathrm{C}\right)$ \\
\hline \multirow[t]{2}{*}{3064} & \multirow[t]{2}{*}{$\begin{array}{c}\text { Carbohydrate } \\
\text { sulfotransferase (ST1) }\end{array}$} & $\mathrm{F}$ & GCACCAAACGGCCACTAAAG & \multirow[t]{2}{*}{51} \\
\hline & & $\mathrm{R}$ & AGGCGTTTTGTGATCTCCGA & \\
\hline \multirow[t]{2}{*}{3265} & \multirow{2}{*}{$\begin{array}{c}\text { Carbohydrate } \\
\text { sulfotransferase (ST2) }\end{array}$} & $\mathrm{F}$ & GGGGACAAGACTGCGTTACA & \multirow[t]{2}{*}{51} \\
\hline & & $\mathrm{R}$ & GAGATTGCGCATTCCGAACC & \\
\hline \multirow[t]{2}{*}{137} & \multirow{2}{*}{$\begin{array}{c}\text { galactose-6 sulfurylase } \\
\text { (SY1) }\end{array}$} & $\mathrm{F}$ & CCCCAGTAGAAACGCGTGAT & \multirow[t]{2}{*}{55} \\
\hline & & $\mathrm{R}$ & GACACCAAGAGTCCACCTCG & \\
\hline \multirow[t]{2}{*}{824} & \multirow[t]{2}{*}{$\begin{array}{c}\text { galactose-6 sulfurylase } \\
\text { (SY2) }\end{array}$} & $\mathrm{F}$ & GACAGCTTCGGTCTAGGAGC & \multirow[t]{2}{*}{55} \\
\hline & & $\mathrm{R}$ & GGTGCAGGTCTTGCGTATCT & \\
\hline \multirow[t]{2}{*}{10,134} & \multirow[t]{2}{*}{ WD40 } & $\mathrm{F}$ & GGCGCACATCCCAATACTT & \multirow[t]{2}{*}{52} \\
\hline & & $\mathrm{R}$ & CTATCAACGCTCTCGCCACT & \\
\hline \multirow[t]{2}{*}{1210} & \multirow[t]{2}{*}{$\begin{array}{l}\text { Cytochrome P450 } \\
\text { (CytP450) }\end{array}$} & $\mathrm{F}$ & CCAGGACACGGATAGACTCG & \multirow[t]{2}{*}{52} \\
\hline & & $\mathrm{R}$ & GAGTGGATACCGTGCTGACA & \\
\hline
\end{tabular}

\subsection{Gene Expressions for Development Stages of Thalli and Cystocarp Maturation}

To determine the transcript levels of two annotated carbohydrate sulfotransferase (henceforth sulfotransferase, ST1 and ST2), and two galactose-6 sulfurylase (henceforth sulfurylase, SY1 and SY2) genes, thalli of $100 \mathrm{mg}$ each at different development stages (fertilised, fertile and infertile thalli) were frozen in liquid nitrogen and stored at $-80^{\circ} \mathrm{C}$ until the RNA was isolated.

To test if gene expression was affected by cystocarp maturity, levels of transcript expression were measured in accordance with the differentiation and development of the cystocarps in the apex of the thalli. In other words, well-developed cystocarps, and mature cystocarps-henceforth, fully-developed cystocarps. The presence of cystocarps was always reported during the spring (April). Pooled thalli 
containing cystocarps at different stages of development were used as a control. Infertile thalli were also used as a control for total absence of cystocarps (winter period, December).

\subsection{Gene Expression Encoding Stress Proteins for Cystocarp Maturity}

Levels of transcripts of two genes encoding stress proteins-i.e., Cytochrome P450 (Cyt P450) and WD40-were determined by cystocarp maturity (well-developed and fully-developed cystocarps). The expressions of infertile thalli without cystocarps were used as controls.

\subsection{Data Analysis}

A one-way ANOVA followed by post hoc tests (Tukey HSD and Dunnett T3) were used to detect significant differences in gene transcript expression levels $(p<0.01)$ during the reproductive stage of thalli, maturity of the cystocarps and under stress.

Author Contributions: P.G.-J. conceived, designed and wrote the manuscript. S.R.M. conducted the experiments. P.G.-J. and R.R.R. discussed the manuscript. All authors have read and agreed to the published version of the manuscript.

Funding: This research was partially supported by the co-operation of the Ministry of Science, Innovation and University and of the University of Las Palmas de Gran Canaria. (Grant CGL2016-78442-C2-2-R, GOBESP2017-04 ULPGC and PROID2017010043 ACIISI; CEI2018-20 ULPGC) to P.G.J.

Conflicts of Interest: No conflicts of interest are declared.

\section{References}

1. Rees, D.A. Structure, conformation, and mechanism in the formation of polysaccharide gels and networks. Adv. Carbohydr. Chem. Biochem. 1969, 24, 267-332. [PubMed]

2. Murano, E.; Jellúš, V.; Piras, A.; Toffanin, R. Cell wall polysaccharides from Gelidium species: Physico-chemical studies using MRI techniques. J. App. Phycol. 1998, 10, 315-322. [CrossRef]

3. Usov, A.I. Polysaccharides of the red algae. In Advance Carbohydrate Chemistry Biochemistry; Horton, D., Ed.; Academic Press: Burlington, NJ, USA, 2011; Volume 65, pp. 115-217.

4. Tasende, M.G.; Cid, M.; Fraga, M.I. Qualitative and quantitative analysis of carrageenan content in gametophytes of Mastocarpus stellatus (Stackhouse) Guiry along Galician coast (NW Spain). J. App. Phycol. 2013, 25, 587-596. [CrossRef]

5. Van De Velde, F. Structure and function of hybrid carrageenans. Food Hydrocoll. 2008, 22, 727-734. [CrossRef]

6. Carrington, E.; Grace, S.P.; Chopin, T. Life history phases and the biomechanical properties of the red alga Chondrus crispus (Rhodophyta). J. Phycol. 2001, 37, 699-704. [CrossRef]

7. Garcia-Jimenez, P. Aclimatación Reproductiva, Fisiológica y Estructural al Cultivo In Vitro del Alga Grateloupia Doryphora (Montagne) Howe (Rhodophyta). Ph.D. Thesis, Universidad de Las Palmas de Gran Canaria, Las Palmas, Spain, 1994.

8. Garcia-Jimenez, P.; Robaina, R.R. Insight into the mechanism of red alga reproduction. What else is beyond cystocarps development? In Systems Biology; IntechOpen: London, UK, 2019. [CrossRef]

9. Garcia-Jimenez, P.; Montero-Fernández, M.; Robaina, R.R. Analysis of ethylene-induced gene regulation during carposporogenesis in the red seaweed Grateloupia imbricata (Rhodophyta). J. Phycol. 2018, 54, 681-689. [CrossRef]

10. Garcia-Jimenez, P.; Montero-Fernández, M.; Robaina, R.R. Molecular mechanisms underlying Grateloupia imbricata (Rhodophyta) carposporogenesis induced by methyl jasmonate. J. Phycol. 2017, 53, 1340-1344. [CrossRef]

11. Mittler, R. ROS are good. Trends Plant Sci. 2017, 22, 11-19. [CrossRef]

12. Tripathy, B.C.; Oelmüller, R. Reactive oxygen species generation and signalling in plants. Plant Signal. Behav. 2012, 7, 1621-1633. [CrossRef]

13. Xu, C.; Min, J. Structure and function of WD 40 domain proteins. Protein Cell 2011, 2, 202-214. [CrossRef]

14. Sun, T.; Tao, H.; Xie, J.; Zhang, S.; Xu, X. Degradation and antioxidant activity of k-carrageenans. J. Appl. Polym. Sci. 2010, 117, 194-199. [CrossRef] 
15. Shukla, P.S.; Borza, T.; Critchley, A.T.; Prithiviraj, B. Carrageenans from red seaweeds as promoters of growth and elicitors of defense response in plants. Front. Mar. Sci. 2016, 3, 81. [CrossRef]

16. Genicot, S.; Préchoux, A.; Correc, G.; Kervarec, N.; Simon, G.; Craigie, J.S. Carrageenans: New tools for new applications. In Blue Biotechnology: Production and Use of Marine Molecules; La Barre, S., Bates, S.S., Eds.; Wiley-VCH Verlag GmbH \& Co. KGaA: Weinheim, Germany, 2018; Volume 1, pp. 371-416. [CrossRef]

17. Genicot-Joncour, S.; Poinas, A.; Richard, O.; Potin, P.; Rudolph, B.; Kloareg, B.; Helbert, W. The cyclization of the 3, 6-anhydro-galactose ring of t-carrageenan is catalyzed by two D-galactose-2, 6-sulfurylases in the red alga Chondrus crispus. Plant Physiol. 2009, 151, 1609-1616. [CrossRef] [PubMed]

18. Garcia-Jimenez, P.; Llorens, C.; Roig, F.J.; Robaina, R.R. Analysis of the transcriptome of the red seaweed Grateloupia imbricata with emphasis on reproductive potential. Mar. Drugs 2018, 16, 490. [CrossRef] [PubMed]

19. Popper, Z.A.; Tuohy, M.G. Beyond the green: Understanding the evolutionary puzzle of plant and algal cell walls. Plant Physiol. 2010, 153, 373-383. [CrossRef]

20. Torres, M.D.; Flórez-Fernández, N.; Domínguez, H. Integral utilization of red seaweed for bioactive production. Mar. Drugs 2019, 17, 314. [CrossRef]

21. Patel, S. Therapeutic importance of sulfated polysaccharides from seaweeds: Updating the recent findings. Biotechnology 2012, 2, 171-185. [CrossRef]

22. Cunha, L.; Grenha, A. Sulfated seaweed polysaccharides as multifunctional materials in drug delivery applications. Mar. Drugs 2016, 14, 42. [CrossRef]

23. Therkelsen, G.H. Carrageenan. In Industrial Gums; Academic Press: Cambridge, MA, USA, 1993; pp. $145-180$.

24. Qin, X.; Ma, C.; Lou, Z.; Wang, A.; Wang, H. Purification and characterization of d-Gal-6-sulfurylase from Eucheuma striatum. Carbohydr. Polym. 2013, 96, 9-14. [CrossRef]

25. Lai, V.M.F.; Wong, P.A.-L.; Lii, C.-Y. Effects of cation properties on sol-gel transition and gel properties of K-carrageenan. J. Food Sci. 2000, 65, 1332-1337. [CrossRef]

26. Casamassimi, A.; Ciccodicola, A. Transcriptional regulation: Molecules, involved mechanisms, and misregulation. Int. J. Mol. Sci. Mar. 2019, 20, 1281. [CrossRef] [PubMed]

27. Garcia-Jimenez, P.; Robaina, R.R. On reproduction in red algae: Further research needed at the molecular level. Front. Plant Sci. 2015, 6, 93. [PubMed]

28. Sacramento, A.T.; Garcia-Jimenez, P.; Robaina, R.R. The polyamine spermine induces cystocarp development in the seaweed Grateloupia (Rhodophyta). Plant Growth Reg. 2007, 53, 147-154. [CrossRef]

29. Hu, R.; Xiao, J.; Gu, T.; Yu, X.; Zhang, Y.; Chang, J.; He, G. Genome-wide identification and analysis of WD40 proteins in wheat (Triticum aestivum L.). BMC Genom. 2018, 19, 803.

30. Garcia-Jimenez, P.; Robaina, R.R. Effects of ethylene on tetrasporogenesis in Pterocladiella capillacea (Rhodophyta). J. Phycol. 2012, 48, 710-715. [CrossRef]

31. Vandesompele, J.; De Preter, K.; Pattyn, F.; Poppe, B.; Van Roy, N.; De Paepe, A.; Speleman, F. Accurate normalization of real-time quantitative RT-PCR data by geometric averaging of multiple internal control genes. Genome Biol. 2002, 3, research0034. [CrossRef]

32. Garcia-Jimenez, P.; García-Maroto, F.; Garrido-Cárdenas, J.A.; Ferrandiz, C.; Robaina, R.R. Differential expression of the ornithine decarboxylase gene during carposporogenesis in the thallus of the red seaweed Grateloupia imbricata (Halymeniaceae). J. Plant Physiol. 2009, 166, 1745-1754. [CrossRef]

(C) 2020 by the authors. Licensee MDPI, Basel, Switzerland. This article is an open access article distributed under the terms and conditions of the Creative Commons Attribution (CC BY) license (http://creativecommons.org/licenses/by/4.0/). 